\title{
A korai fejlesztéstől a családközpontú kora gyermekkori intervencióig. A törvényi szabályozástól az interdiszciplináris szemlélet és gyakorlat megvalósulásáig a Budapesti Korai Fejlesztő Központban
}

\author{
Czeizel Barbara - Kemény Gabriella: \\ Budapesti Korai Fejlesztő Központ
}

\begin{abstract}
A tanulmány kísérletet tesz annak bemutatására, hogyan változott a szakmai terminológia a korai fejlesztéstől a családközpontú kora gyermekkori intervencióig. Ezzel párhuzamosan bemutatjuk a Budapesti Korai Fejlesztő Központ szemléletbeli és gyakorlatbeli változásának útját a Központ kulcskompetenciáin keresztül, különös tekintettel az interdiszciplinaritás megvalósulására az eltérő fejlődésü kisgyermekek ellátása során.
\end{abstract}

Kulcsszavak: családközpontú kora gyermekkori intervenció, gyermek körül felálló interdiszciplináris team, partnerség, rizikócsecsemők, fogyatékos kisgyermekek

\begin{abstract}
„Nekem az az első vizsgálat meghatározó élményt jelentett. Nemcsak a fejlesztések további menetére gondolva, hanem - és elsősorban - a kisfiammal való kapcsolatom alakulásában is. Egy jelentéktelen momentumnak látszó dolog történt: az egyik szakember kedvesen mosolyogva megkérdezte, felveheti-e Mátét. Persze - válaszoltam azonnal szintén mosolyogva, de nehéz megfogalmazni, hogy akkor mi zajlott le bennem néhány pillanat alatt. Eddig ilyet soha senki nem kérdezett tölem. Máté egy eset volt, akivel egyértelmüen ezt meg azt csinálni kellett és nyilván én mint kötelességtudó anyuka átengedem „szabad felhasználásra” az Esetet. Megdöbbentő volt a felismerés - katartikus. Elöször vett minket egy szakember emberszámba, elöször éreztem, hogy Mátéban meglátja a kisbabát - az embert... Abban a furcsa, valóságból kissé kiragadott lelkiállapotban nem jegyeztem meg, ki volt az. Most sem tudom, de azóta is hálás vagyok neki, mert tőle kaptuk vissza a megtépázott méltóságunkat. Attól kezdve tudtam Máténak tudatosan is az édesanyja lenni. Köszönöm neki!"
\end{abstract}

(Borbély és Kovács, 2012)

\section{Korai fejlesztéstől a családközpontú kora gyermekkori intervencióig}

Az European Agency for Development in Special Needs Education szervezetnek a kora gyermekkori intervenció európai gyakorlatáról 2005-ben, majd 2009-ben újra megjelent összegző dokumentuma határozottan megkülönbözteti a korai fejlesztés fogalmát a kora gyermekkori intervenció kifejezéstől. Eszerint a korai fejlesztés minden olyan időben nyújtott cselekvést és beavatkozást magában foglal, amelyben a sajátos nevelési igényű gyermek és családja a nevelési-oktatási folyamat során részesül. A kora gyermekkori intervenció ellenben a hat évnél nem idősebb, eltérő fejlődésű és rizikógyermekekre és családjukra fókuszál. A nemzetközi gyakorlatnak megfelelően a projekt a kora gyermekkori intervenció terminológiát használja (ECIPU, 2005, 2010).

A családközpontú kora gyermekkori intervenció a 0-5 (6) éves korú sérült, fogyatékos, eltérő fejlődésủ és viselkedésű illetve fejlődési zavar szempontjából veszélyeztetett csecsemők illetve gyermekek tervszerüen felépített programja; a család segítése, mely

- szürést,

- komplex diagnosztikai vizsgálatot,

- komplex gyógypedagógiai fejlesztést és tanácsadást, 
- különböző terápiás szolgáltatásokat,

- a gyermek egyéni szükségleteinek megfelelő gyermekközösségbe kerülés támogatását foglal magában, a gyermek állapotát és a család körülményeit, valamint egyedi igényeit figyelembe véve (Czeizel, .2009a, 2009bs).

Korai fejlesztésben 0-5 éves korig, intervencióban a születéstől iskolába kerülésig részesülhetnek rizikócsecsemők, az értelmi, érzékszervi, mozgás- és halmozottan sérült, valamint a viselkedés, kommunikáció és szociális kapcsolat terén zavarral küzdő gyermekek. A korai intervenciós, fejlesztő programok célja a sérült, fogyatékos, eltérő fejlődésű és viselkedésű illetve fejlődési zavar szempontjából veszélyeztetett gyermekeket nevelő családok segítése, a gyermek sérült, vagy lassabban kialakuló készségeinek fejlesztése, a jobb életminőség és a szociális kapcsolatok támogatása (Czeizel, 2010).

A kora gyermekkori intervenciónak tehát a tervezett-szervezett nyomon követés ugyanúgy célja, mint a diagnosztikus vizsgálat, vagy a terápiák. A választás nem függhet mástól, csakis a gyermek illetve a család szükségleteitől, igényeitől (Czeizel, Tóth és Kemény, 2011).

\section{Intézményünk, a Budapesti Korai Fejlesztő Központ története a változó szemlélet tükrében}

1991-ben három fiatal szakember, különböző motivációkból, különböző helyről jőve azonos célt fogalmaztak meg: létre kell hozni egy olyan helyet, intézményt, ahol azok a családok, akiknek eltérő fejlődésü kisbabája születik, vagy kisgyermekük van, egy helyen kapjanak különböző szakemberek által olyan segítséget, mely valóban segítség számukra. Ez a három szakember dr. Gallai Mária, Dubecz Dorottya és Czeizel Barbara. Tisztában voltunk azzal, hogy ez a típusú szolgáltatás, mely az akkori gyakorlatot figyelembe véve nem volt általánosnak nevezhető, sőt, a családokat partnerként fogadta, és egy épületben, azon belül is akár egy szobában, de mindenképpen egy nagyon együttmüködő team formájában dolgozott együtt és próbálta a különböző szaktudásokat együttes gondolkodássá alakítani. Ez az akkori egészségügyi, szociális, és oktatási alapellátáson belül nem volt reálisan kivitelezhető. Így némileg az ismeretlenbe belevágva 1991-ben egy alapítványt hoztunk létre, a Korai Fejlesztő Központot Támogató Alapítványt, mely fenntartója lett intézményünknek.

Az alapítvány megalakulása és az intézmény működésének 1992-es megkezdése között eltelt egy évben célunk volt, és sikerült is megvalósítanunk, hogy végiglátogassuk, napokat töltsünk el azon állami és nem állami, egészségügyi, szociális és oktatási szolgáltatóknál, akik tudomásunk szerint fogadták a 0-6 éves korú eltérő fejlődésű kisgyermekeket és családjaikat. Ez nagyon fontos tapasztalatszerzés volt arra nézve, hogy valóban, személyes élményen keresztül ismerjük meg az ellátórendszer különböző szolgáltatásait, módszereit és az ott dolgozó szakembereket. llyen formán egy ellátási térkép alakult ki számunkra, mely a valós, a szolgáltatók által közölt egyediségüket és kereteiket tükrözte vissza számunkra. Nem utolsó sorban, nagyon hasznos volt, hogy személyesen tudtunk találkozni eszmét és tapasztalatot cserélni a terület szakembereinek kiválóságaival. Ez a mai napig az egyik legerősebb szakmai tőkénk. A hazai tapasztalatokon túl - különböző ösztöndíjakkal, elsősorban a Soros Alapítvány támogatásával - jutottunk el olyan országokba, ahol a korai fejlesztés, a kora gyermekkori intervenció már több évtizedes múltra tekinthetett vissza. Sokat tanultunk az amerikai, az angol, a német, a holland modellekből is. Ezen elméleti és gyakorlati ismeretekből, tapasztalatokból alakítottuk ki azt a sajátos, a magyar ellá- 
A korai fejlesztéstől a családközpontú kora gyermekkori intervencióig. A törvényi szabályozástól...

tórendszerben addig alig megjelenő szolgáltatást, mely elsősorban a 0-6 éves korú, eltérően fejlődő gyermekek és családjaik egyedi szempontjait figyelembe vevő, komplex, több szakember általi, több terápiát együttesen képviselő, akkoriban, és ma, a már átalakuló félben lévő szemlélet mellett is korai fejlesztésnek nevezett tevékenységet biztosította. Mai szóhasználatunkban a szemlélettel összhangban, és az ellátási gyakorlatnak megfelelően a családközpontú kora gyermekkori intervenció kifejezést használjuk, és terjesztjük.

Szolgáltatásaink a hozzánk forduló családok által megjelenített igények alapján alakultak. Gyermek-szakorvosaink idővel további szakvizsgával gyarapították szaktudásukat, így a mai napig gyermekorvos-gyermekpszichiáter, illetve gyermekorvosgyermekneurológus is tagja a csapatunknak. Gyógypedagógus kollégáink folyamatosan tovább képezték, képezik magukat. Egyre több két szakos munkatársunk lett, így gyógypedagógus-pszichológus, vagy gyógypedagógus-gyógytornász, de ezt a felsorolást lehetetlen a teljesség igényével leírni. Munkatársaink az ellátott gyermekek életkori és fejlődési sajátosságainak megfelelően szereztek, és a mai napig is szereznek további specifikus szakmai tudást, gyakorlatot, az extrém koraszülöttektől az autizmussal élő kisgyermekeken át a súlyosan - halmozottan sérült magas színvonalú ellátásához.

Civil szervezetként az elmúlt húsz évben a családok ellátásán túl kiemelt feladatunk volt az a szakmapolitikai tevékenység, melynek célja a már korábban említett három ágazat, az egészségügy, a szociális és oktatási ágazat valós szakmai együttmüködésének és kommunikációjának elérése az érintett családok folyamatos megfelelő minőségű szakmai ellátásának érdekében. Ez a Központ életében egy átmeneti pillanatban megvalósult, hiszen a közoktatási, köznevelési megállapodásunk és az OEP-pel kötött szerződésünk mellet szociális módszertani feladatot láttunk el két-három éven át. $A z$, hogy ez a tárcaközi, ágazatközi összefogás rendszerszinten is látható, érzékelhető legyen, még több 20 év után is várat magára. Beszámolhatunk azonban arról, hogy megszületett a szándéknyilatkozat az egészségügyi, szociális és köznevelési ágazat részéről az eltérő fejlődésű kisgyermekek és családjaikat érintő jogszabályok és szolgáltatások összehangolására és a specifikus területek fejlesztésére, ami az elmúlt évtizedeket figyelembe véve nagyon nagy eredménynek tekinthető. Ugyanakkor, ennek a ténynek tudatában, továbbá megtapasztalva azt, hogy a családokat képviselve nekünk, szakembereknek összefogva is kell tennünk az országos, alanyi jogon elérhető megfelelő minőségü kora gyermekkori intervenciós szolgáltatások biztosításáért, folyamatosan képzéseket dolgoztunk ki, akkreditálunk, amelyek a területet érintő szakemberek továbbképzéséről hivatottak gondoskodni az ország minden régiójából.

Intézményük az elmúlt időszakban és reményeink szerint a jövőben is képes lesz követni az ellátásra jogosult családok igényeit, és a komplex diagnózist nyújtó vizsgálattól, a nyomon követést biztosító folyamat és a kontrollvizsgálatokon, az egyéni illetve csoportos gyógypedagógiai fejlesztésen, tanácsadáson át, a különböző mozgásterápiákig, továbbá zene-, hangtál- és állatasszisztált terápiákig. Az ambuláns ellátás mellett 2003 óta két, Magyarországon különösen halmozottan hátrányos helyzetü, fogyatékossággal élő gyermekcsoportnak biztosítunk nappali ellátást. Ők az autizmussal élő és a súlyosan-halmozottan sérült gyermekek, akik számára jelenleg nappali ellátó csoportokat, illetve gyógypedagógiai óvodai csoportot müködtetünk.

A saját hétköznapi túlélési küzdelmeink megvívása mellett, változatlanul célunk az érintett családok életminőségének javítása, mindennapjainak könnyebbé tétele közvetlenül és közvetve, a szakemberek képzésével, továbbképzésével egyaránt. 
Újabb kihívás a Budapesti Korai Fejlesztő Központ számára, hogy szakmai felügyeletünk mellett, és munkatársaink oktatói tevékenysége által 2013 februárjában indult az ELTE Bárczi Gusztáv Gyógypedagógiai Karon az első Családközpontú kora gyermekkori intervenció szakirányú szak, mely terveink szerint jelentős minőségi lépés lesz az ellátó rendszerben dolgozók megfelelő szakmai támogatásához, ezáltal támogatva a kora gyermekkori intervenciós szolgáltatási háló kiépítését Magyarországon (Czeizel, 2012).

A Budapesti Korai Fejlesztő Központ elsődleges tevékenysége Budapesten és vonzáskörzetében élő 0-3 (5) éves korú, eltérő fejlődésű, fogyatékos kisgyermekek diagnosztikai vizsgálata, egyéni és csoportos ambuláns fejlesztése, speciális terápiák biztosítása, valamint a szülőknek nyújtott tanácsadás kapcsán családok segítése. Emellett helyet kap a már említett két nappali ellátást biztosító program: 3-4 éves kort betöltött, autizmussal élő, és a 3 év feletti fejlődésmenetükben jelentősen akadályozott (súlyosan-halmozottan sérült) gyermekek ambuláns csoportos, közösségi elhelyezést bevezető fejlesztése és gondozása.

A kora gyermekkori intervenció ezen gyermekek tervszerűen felépített fejlesztőprogramja, mely komplex diagnosztikai vizsgálatot, gyógypedagógiai fejlesztést, tanácsadást és különböző terápiás szolgáltatásokat foglal magába. Korai fejlesztésre, intervenciós szolgáltatásokra azok a gyermekek jogosultak, akik megfelelő differenciáldiagnosztikai vizsgálómódszerrel elvégzett vizsgálat során elmaradást mutatnak a mozgásfejlődés, az értelmi fejlődés, a kommunikáció, a beszédfejlődés, a szociális, érzelmi fejlődés, a figyelem, magatartás és/vagy a látás, hallás területén. Emellett a korai fejlesztés szükségességét állapítjuk meg olyan diagnosztizált állapotokban, amelyek következménye nagy valószínüséggel fejlődési elmaradás lehet a későbbiekben.

A 2011. évi CXC. köznevelési törvény 47. § (1) bekezdése értelmében „A sajátos nevelési igényű gyermeknek, tanulónak joga, hogy különleges bánásmód keretében állapotának megfelelő pedagógiai, gyógypedagógiai, konduktív pedagógiai ellátásban részesüljön attól kezdődően, hogy igényjogosultságát megállapították. A különleges bánásmódnak megfelelő ellátást a szakértői bizottság szakértői véleményében foglaltak szerint kell biztosítani."

A 15/2013. (II.26.) EMMI rendelet 4. § (1) bekezdése szerint „a gyógypedagógiai tanácsadás, korai fejlesztés, oktatás és gondozás (a továbbiakban: korai fejlesztés és gondozás) feladata a komplex kora gyermekkori intervenció és prevenció: az ellátásra való jogosultság megállapításának időpontjától kezdődően a gyermek fejlődésének elősegítése, a család kompetenciáinak erősítése, a gyermek és a család társadalmi inklúziójának támogatása. A korai fejlesztés és gondozás tevékenységei a komplex gyógypedagógiai fejlesztés, tanácsadás, a társas, a kommunikációs és nyelvi készségek fejlesztése, a mozgásfejlesztés és a pszichológiai segítségnyújtás." (BKFK, 2014)

\section{Korai intervenciós szolgáltatások a Budapesti Korai Fejlesztő Központban és ezek megvalósulása az interdiszciplináris szemlélet és gyakorlat tükrében}

\section{A diagnosztikus vizsgálat}

\section{Központunk vizsgálati szemlélete}

A komplex gyógypedagógiai - pszichológiai vizsgálati modell a biológiai tényezők feltérképezése mellett, az egyén pszichológiai és szociológiai profiljának a megismerésére is kiterjed. A teljes klinikai kép feltárása több szempontú, komplex megközelítés alapján történik: kóroki, pedagógiai, pszichológiai és szociális szempontú 
A korai fejlesztéstől a családközpontú kora gyermekkori intervencióig. A törvényi szabályozástól...

megközelítés. Az állapot leírásánál ma már az akadályozott, kóros működések megállapítása mellett jelentős hangsúlyt kap a gyermek erőforrásainak, ép funkcióinak feltérképezése, megfogalmazása. Ez az alapja és kiinduló pontja a szükséges beavatkozások meghatározásának, valamint a folyamatdiagnosztikának. A fejlődés, az állapot változásának nyomon követése, nem csak kontrollvizsgálatok alkalmával és pszichometriai eljárások alkalmazása révén valósul meg, hanem a fejlesztési helyzetek során történő rendszeres, tudatos és módszeres megfigyeléssel is. A differenciáldiagnosztikai szempontok értékelésének szempontjai is korszerüsödtek, a normál és az eltérő fejlődés meghatározása, a fejlettségi szint leírása, számszerüsítése, mind a gyermeki fejlődés dinamikájának ismeretében kezelendők, és a megfelelő fejlesztési lehetőségek megtalálását, a fejlődés kilátásainak megfogalmazását célozzák. A számszerűsített, globális mutatókra épülő diagnózisok a gyakorlatban nehezen használhatók, ha figyelmen kívül hagyjuk a viselkedés körülményeinek komplexitását és a környezet befolyásoló szerepét. A megismerés nemcsak a gyermekre magára, hanem az őt körülvevő környezetre is vonatkozik.

Az aktuális állapot megismeréséhez való hozzájárulás az orvosi diagnosztika eszközeivel, gyermekneurológiai, gyermekpszichiátriai vizsgálattal történik. Ezen kívül müszeres, laboratóriumi, képalkotó vizsgálatok megszervezésére van lehetőség konzulens szakorvosok segítségével. Mindez az etiológiai - kóroki háttér kiderítése, és a medicinális terápiák (konzervatív esetleg mütéti) indukálása miatt fontos lehet. Az orvosi konzultációk és a kontrollvizsgálatok alkalmával történő nyomon követés a folyamatdiagnosztikának is fontos részét képezi. A neurológia más társtudományokkal (pszichológia, gyógypedagógiai pszichológia, pszichodiagnosztika) karöltve, annak lehetőségét hordozza, hogy bizonyos kórformák, nehezen értelmezhető teljesítményproblémák, klinikai képek esetén nagyobb biztonsággal lehessen a diagnosztikus dilemmákat megoldani.

A családokkal való első találkozás tehát mindenképpen több szakterület együttes jelenléte mellett történik az interdiszciplináris együttmüködés megvalósításával (gyermekszakorvos, gyógypedagógus/pszichológus, és a teamtől függően mozgásfejlesztő szakember). Együttes tudásuk a komplex diagnózis megállapításán kívül ahhoz is szükséges, hogy a problémával ebben az időszakban szembesülő szülőknek a lehető legpontosabban fogalmazzák meg gyermekük állapotát, a vizsgálaton tapasztaltak értelmezését, a várható kilátásokat és lehetőségeket. Fontos, hogy megpróbálják felmérni, az adott pillanatban mi a legfontosabb a család és a gyermek számára. Ez alapján javaslatot tesznek a szülöknek, hogy a még esetlegesen szükséges szakorvosi vizsgálatok mellett, mely segítő szakemberekkel tudják felvenni a kapcsolatot, illetve milyen formában lehet majd együttműködni velük. Ennek az együttmüködésnek a kulcspontja a szakemberek tájékozódása és a szülök eligazítása a különféle terápiák és fejlesztő eljárások között. A szakembereknek nagy felelősségük van abban, hogy a lehető legközelebbről ismerjék meg a különböző fejlesztési lehetőségeket, módszereket, a gyermek diagnózisának, állapotának és életkorának leginkább megfelelő terápiákat válasszák ki a szülők attitüdjének, képességeinek, valamint a család lehetőségeinek figyelembe vételével, majd legjobb tudásuk szerint ismertessék a javasolt módszereket. A fejlesztő munka kiindulópontja a kóroki diagnózis mellett a fejlődési diagnózis felállítása.

\section{A vizsgálat részei:}

\section{A vizsgálatra való felkészülés}

A vizsgálatra jelentkező családok részletes kérdőívet töltenek ki gyermekükről, emellett beküldik a gyermek korábbi zárójelentéseit, vizsgálati eredményeit, és ha közösségbe jár, akkor kérjük a gyermeket ellátó kisgyermekgondozók, óvónők által megfogalmazott 
pedagógiai véleményt. Az így megkapott információkat feldolgozva a Budapesti Korai Fejlesztő Központ munkatársai a korábban felállított diagnózisok, a szülők részéről felmerülő aggodalmak, és kérések alapján alakítják ki a vizsgáló team („kis-team”) összetételét.

A neurológiai vizsgáló team tagjai:

- gyermekneurológus

- gyógypedagógus, gyógypedagógus-pszichológus

- mozgásterapeuta

Pszichiátriai vizsgáló team tagjai:

- gyermekpszichiáter

- gyógypedagógus, gyógypedagógus-pszichológus

- logopédus

- pszichológus

- szükség esetén mozgásterapeuta

A neurológiai vizsgálati team feladata: A minden fejlődési területre kiterjedő részletes, összetett vizsgálat célja, hogy megállapítsa a gyermek kóroki, és fejlődési diagnózisát, fejlettségi állapotát a pszichomotoros fejlődés különböző területein. A pszichiátriai vizsgálati team feladata: Annak megállapítása vagy kizárása, hogy a gyermeknél fennáll-e pervazív fejlődési zavar, vagy egyéb pszichés fejlődési zavar: figyelem- vagy magatartásszabályozási, beilleszkedési nehézség, a társas kapcsolatokban megjelenő akadályozottság, illetve a kommunikációs és nyelvi készségek terén felismerhető problémák.

\section{A vizsgálati folyamat}

A vizsgálatra a gyermeket mindkét szülővel együtt várjuk (amennyiben csak egy szülő érkezik, ő nyilatkozik a másik szülő képviseletéröl). A családok előre megbeszélt időpontra érkeznek, várakozási idő nincsen. Egy alkalommal 2 órányi idő áll rendelkezésre. A szülők engedélyével a vizsgálat közben néhány perces videófelvételt készítünk belső használatra, a vizsgálati esetmegbeszélő teamen („Nagy-team”) való megbeszélésre, valamint a dokumentáció részeként archiválásra. A vizsgálaton a szülők természetesen minden esetben végig jelen vannak.

A vizsgáló team („Kis-team”) feladata - a vizsgálat előtt és alatt - a gyermek eddigi élettörténetének részletes áttekintése, mind orvosi (családi előzmények, anyai betegségek, a terhesség alatt és a születés körül jelentkező problémák, illetve a megszületés óta eltelt időszak adatai, az eddigi betegségek, kórházi kezelések), mind gyógypedagógiai szempontból (a fejlődés eddigi mérföldkövei a nagy- és finommozgások, beszéd és kommunikáció, a szocializáció, a játék és érdeklődés, a viselkedés és az önállóság terén). Itt esik szó a már korábban elvégzett kivizsgálásokról, illetve az eddig alkalmazott kezelésekről, esetleges fejlesztési módszerek eddigi alkalmazásáról, és azok eredményeiről.

A részletes gyógypedagógiai, illetve szükség esetén pszichológiai vizsgálat során a gyógypedagógus/pszichológus (és adott esetben a mozgásterapeuta) megfigyeli a gyermek spontán viselkedését, játékát és mozgását, illetve a szülőkkel való kapcsolatát. Ezt követően azt a vizsgálati eszközt, módszert alkalmazzuk a csecsemő/ gyermek fejlettségi szintjének felmérésére, amely a kérdőív adatai, illetve a gyermek spontán tevékenységének megfigyelése alapján a legmegfelelőbbnek tűnik (fejlődési skálák, fejlődési tesztek, illetve intelligencia tesztek valamelyike).

Ezt követően történik meg a gyógytornász/mozgásterapeuta által végzett mozgásvizsgálat, amely a nagy- és finommozgások fejlődésének zavaraira, késéseire fókuszál.

A komplex vizsgálat utolsó részében, az addig anamnézist felvevő és megfigyelő szakorvos a részletes orvosi vizsgálat keretében, de „barátságos körülmények” között méri fel az idegrendszer működésének, esetleges működési zavarainak állapotát. 
A korai fejlesztéstől a családközpontú kora gyermekkori intervencióig. A törvényi szabályozástól...

A vizsgálat folytatása

Amennyiben a diagnózis nem állítható fel egyértelműen az első vizsgálati alkalom folyamán, a szokásos vizsgálati idő alatt, a vizsgálatot célirányosan folytatjuk. Ilyenkor egy újabb vizsgálati időpontot egyeztetnek szakembereink a családdal. A kiegészítő vizsgálatok, pl. ADOS és egyéb differenciáldiagnosztikai vizsgálatok, illetve beszéd- és mozgásvizsgálat lehetnek. Ha szükséges, a vizsgáló team tagjai a szülők engedélyével felveszik a kapcsolatot a gyermeket ellátó intézmény szakembereivel.

\section{A „kis-team” szerepe}

A vizsgálat tapasztalatait először a vizsgálaton résztvevő két/három szakember vitatja meg egymással. „Házi használatban” ezt a megbeszélést „kis-team”-nek hívjuk. Ekkor az interdiszciplináris team szakemberei közös nevezőre próbálnak jutni a diagnózist illetően, javaslatot fogalmaznak meg a gyermek további kivizsgálására és ellátására vonatkozóan.

\section{A vizsgálati team (,nagy-team”)}

Minden héten egy alkalommal valamennyi, azon a héten megvizsgált gyermek vizsgálatát egy közös team-megbeszélésen ismertetik a vizsgálók. Ekkor kerül levetítésre az elkészített videófilm is. Ezen a megbeszélésen minden munkatárs jelen van, aki a diagnosztikai munkában részt vesz. Az esetismertetés protokollja az alábbi: a gyermekneurológus-, ill. pszichiáter szakorvos ismerteti az gyermek és a család anamnesztikus adatait, a szülök által megfogalmazott problémákat, kérdéseket és igényeket, valamint a szakorvosi vizsgálat eredményét. Erre épülve foglalják össze a pszichomotoros fejlődés vizsgálatát végző szakemberek (gyógypedagógus, vagy pszichológus, és mozgásterapeuta) a vizsgálaton megfigyelteket, és a vizsgálat eredményét. A felmerülő kérdéseket, diagnosztikai dilemmákat a team tagjai elé tárják, hogy a javaslatot konszenzusos módon kialakítsuk. Ez tartalmazza az adott gyermek szükségleteinek megfelelő fejlesztési és terápiás tervét (módszerek, azok formája, gyakorisága, az ellátó szakemberek végzettsége, intézmény típusa).

Ezen a megbeszélésen tehát a többéves diagnosztikai tapasztalattal bíró munkatársak, és az intézményvezető is észrevételeket és javaslatokat tehetnek a diagnózissal, a kivizsgálással, a javaslattal, vagy a gyermek elhelyezésével kapcsolatban. A végső javaslatot, és a gyermek fejlődési diagnózisát tehát a vizsgálók („Kis-team”), és a többi szakember („Nagy-team”) közösen alakítják ki az interdiszciplináris szemlélet és gyakorlat alkalmazásával, majd ezt fogják képviselni a szülőkkel folytatott megbeszélés alkalmával.

Amennyiben a család Intézményünkben kéri a gyermek ellátását, a teamben választják ki a gyermek életkorának, és specifikus problémájának megfelelő végzettséggel és tapasztalattal bíró fejlesztő, és egyéb terápiás munkatársakat. Más intézményben történő ellátás esetén, amennyiben a szülő igényli, felvesszük a kapcsolatot az ottani szakemberekkel. Információs adatbázisunk tartalmazza a korai fejlesztés országos ellátóinak, intézményeinek listáját, melyet igyekszünk naprakészen frissíteni.

\section{A szülökkel történő megbeszélés}

A szülőkkel az esetek túlnyomó többségében egy külön időpontban beszéljük meg a vizsgálaton tapasztaltakat és a konszenzusos javaslatot. Erre részben azért van szükség, mert így több idő áll rendelkezésünkre a vizsgálat eredményének közlésére és értelmezésére, valamint a javaslat megvitatására a családdal, részben pedig azért, mert ha a szülök a megbeszélésre a gyermek nélkül tudnak eljönni, akkor a körülmények is sokkal nyugodtabbak, megfelelőbbek egy elmélyült, odafigyelő beszélgetésre. A megbeszélés során a vizsgálatot végző szakembercsoport javaslatot tesz a 
családnak az esetleges további szakorvosi és egyéb vizsgálatokra, az egészségügyi és pedagógiai terápiás, fejlesztési segítségnyújtás lehetőségeire, mindezt természetesen a család igényeinek figyelembevételével, a szülőkkel egyeztetve.

\section{Kontrollvizsgálatok végzése}

Többnyire évenkénti - szükség esetén ennél gyakoribb - kontrollvizsgálatokat is felajánlunk a családoknak. Ennek során felmérjük a gyermek fejlődési ütemét, megvitatjuk a szülőkkel az eddig elért eredményeket, és szükség esetén kiegészítjük, módosítjuk a már alkalmazott fejlesztési, terápiás tervet. A fejlesztést végző szakember számára visszajelzést, a szülőnek tájékoztatást, az elfogadási folyamat segítését jelenti a folyamatdiagnózis, az időszakos kontrollvizsgálat. A korai fejlesztés lezárása, és a megfelelő közösségi elhelyezés megkeresése is célja lehet egy ismételt vizsgálatnak.

\section{A vizsgálati vélemény elkészítése}

A vizsgálat eredményeiről minden esetben részletes, írásos szakvéleményt készítenek a vizsgáló team tagjai, melyet eljuttatunk - a megbeszélést követően 15 napon belül - a szülöknek. Mind a megbeszélések, mind a szakvélemények készítése során arra törekszünk, hogy a szülők számára érthető és elfogadható kifejezéseket használjunk. Célunk, hogy a szülők egyenrangú partnereknek érezhessék magukat a gyermekük további sorsát érintő kérdések megbeszélésében, és hogy a számukra helyes döntések meghozatalához a lehető legtöbb szükséges információ a rendelkezésükre álljon.

\section{A szükséges kiegészítő szakorvosi vizsgálatok megszervezése}

Amennyiben a diagnózis pontos megállapításához, illetve a megfelelő ellátás megtervezéséhez további vizsgálatokra van szükség, ezek megszervezésében is segítségére vagyunk a családnak. A Központban vizsgált gyermekek esetében leggyakrabban genetikai, gyermekpszichiátriai, gyermekneurológiai, gyermekszemészeti, anyagcsere-, illetve gyermekortopédiai vizsgálat elvégzése szükséges.

A javasolt szakorvosi ellátásokat végző orvosokkal szoros konzulensi, együttmüködési kapcsolatot építettek ki, melynek segítségével a családok könnyebben hozzájuthatnak a szükséges szakorvosi vizsgálatok elvégzéséhez, illetve ha szükséges, rendszeres gondozásban részesülhetnek.

\section{A Budapesti Korai Fejlesztő Központban biztosított egyéni és csoportos fejlesz- tések, terápiák és tanácsadás a kora gyermekkori intervenció, fejlesztés területén} A gyermek komplex vizsgálata alapján a gyermek fejlődési profiljának ismeretében és a család igényeit figyelembe véve igyekszünk a lehető legtöbb és legmegfelelöbb segítséget nyújtani. Alapvető céljaink között szerepel, hogy a család számára - amenynyiben ők nálunk kérik az ellátást - lehetőleg az intézményen belül biztosítsunk minden olyan szolgáltatást, amelyre a gyermeknek szüksége van. Ellátási rendszerünkben minden család, illetve gyermek gyógypedagógusa a gyermek körül felálló interdiszciplináris fejlesztő/terápiás team koordinátora, aki összehangolja a család számára felajánlott szolgáltatásokat, és időről időre konzultációs találkozót szervez a gyermek ellátásában résztvevő többi szakemberrel.

A családoknak nyújtott szolgáltatások formái a következők lehetnek:

- Egyéni, komplex gyógypedagógiai fejlesztés és tanácsadás, melynek során a gyógypedagógus, megismerve a gyermek fejlődési profilját, a gyermek erősségeire alapozva segíti a megkésett területeken a fejlődést. Mivel a fejlesztés ambu- 
A korai fejlesztéstől a családközpontú kora gyermekkori intervencióig. A törvényi szabályozástól...

láns rendszerben történik, a cél az, hogy a gyermek mindennapi, otthoni fejlesztéséhez mintát nyújtsunk, s azt a szülőkkel való konzultáció során a mindennapi élet helyzeteire vonatkoztassuk. Nagy hangsúlyt fektetünk a fejlesztésekhez kapcsolódó, szülővel folytatott beszélgetésekre. Központunk alapszemlélete és alapgyakorlata a korai intervenció, ezért ezek a beszélgetések az otthoni helyzetek alapos elemzésére építve, a gyermek és a vele együtt élő családtagok interakcióira, napi rutinjára vonatkozó tanácsadást, valamint a gyermek akadályozottságából, eltérő fejlődéséből fakadó nehézségek, problémák megoldásának közös keresését tartalmazzák. A gyógypedagógusok a gyermek állapota és a család igénye alapján a gyermek otthonában is látogatást tesznek, valamint ha a gyermek közösségbe jár, a gyermekközösségben is felkeresik, konzultálnak az ott dolgozó szakemberekkel. A gyógypedagógiai fejlesztés területei: kognitív-gondolkodó terület fejlesztése, figyelem-koncentráció fejlesztése, finommotorika területének fejlesztése, beszéd (beszédészlelés, beszédértés és beszédprodukció) és kommunikáció fejlesztése, szociális-érzelmi terület fejlesztése, önkiszolgálás terén, önállóságra segítés. A gyógypedagógiai fejlesztést végezhetik: gyógypedagógusok, akik a korai segítségnyújtás elméletében és gyakorlatában ismereteket és tapasztalatokat szereznek. A gyógypedagógus egyben a gyermek körül felálló interdiszciplináris fejlesztő/terápiás team koordinátora is. A gyógypedagógus a gyermek állapotának és problémáinak megfelelően foglalkozhat evéssel, alvással, szobatisztasággal kapcsolatos és a gyermek és a család mindennapjait meghatározó nehézségekkel. A korai intervenciónak, a gyógypedagógiai tanácsadásnak szerves részét képezi az információk nyújtása a családok számára a gyermek fogyatékosságával, eltérő fejlődésével összefüggő egészségügyi, szociális (juttatások, jogosultságok) pszichológiai, nevelési és pedagógiai kérdésekkel kapcsolatban. Fontos szempont az érdekérvényesítéssel kapcsolatos segítségnyújtás, tanácsadás. Mivel Központunkban a gyermekek ambuláns ellátását, fejlesztését legfeljebb 5 éves korukig tudjuk vállalni, munkatársaink segítséget nyújtanak a családoknak a gyermek számára legmegfelelőbb gyermekközösség, illetve további fejlesztési módszerek és intézmények megkeresésében. Szükség esetén a család lakhelye szerint illetékes Pedagógiai Szakszolgálattal, EGYMI-vel, Családsegítő és Gyermekjóléti Szolgálattal való kapcsolatfelvételben, vagy más hivatalos szervekkel való együttmüködésben is segítünk a családoknak (Tóth, 2000).

- Csoportos gyógypedagógiai fejlesztés intézményünkben: Amennyiben a gyermek szociális fejlődése és életkora lehetővé, vagy szükségessé teszi, csoportokat hozunk létre hasonló típusú sérültséggel élő gyermekek számára, hogy az itt zajló foglalkozások során a gyógypedagógiai segítségnyújtás mellett a gyermekközösséghez való hozzászoktatást, a szülők számára pedig a segítő sorstársi kapcsolatok kialakulását is előmozdítsuk.

- Mozgásterápiát nyújtunk minden olyan gyermek számára, akinél a tartási és/ vagy mozgási funkciók elsődleges vagy másodlagos sérülése áll fenn. A sérülés lokalizációja, az etiológiai diagnózis, a tünetek súlyossága, a kórlefolyás és a társuló fogyatékosságok mind meghatározhatják, hogy a funkcionális kezelés elegendő-e az érintett motoros működés helyreállítására (pl. enyhe fokú generalizált izomhipotónia) vagy komplex rehabilitációs tevékenység megszervezésére van-e szükség. Azok a gyermekek, akiknek a nagymozgásuk fejlődésében is megkésettség vagy eltérés mutatkozik, mozgásterápiában részesülnek. A gyermekről készített egyéni mozgásfejlesztési tervben rövid és hosszú távú célokat határozunk meg. Ezen célok eléréséhez többféle módszer áll rendelkezésünkre. A gyermek etiológiai diagnózisától, mozgásállapotától, életkorától, értelmi képességétől és együttmüködő készségétől függően részesülhet a következő terápiákban. A különböző mozgásterápiák alkalmazásának lehetőségét és szükségességét mindig az egyes gyermeket vizsgáló, illetve ellátó szakemberek, azaz a team konszenzusos javaslata alapján tárjuk a szülők elé. 
- Egyéni aktív gyógytorna: csecsemő-életkor esetén, súlyos mozgássérülés, súlyos fokú érzékszervi sérülés, jelentős értelmi akadályozottság, súlyoshalmozott sérülés, magatartás-, viselkedésprobléma esetén javasoljuk. Nem módszer-specifikus, a bázistechnikák alkalmazásával biztosított terápia a megkésett, illetve eltérő mozgásfejlődésű gyermekek számára. Egyénre szabott fejlesztési terv és gyakorlatanyag alapján dolgozunk, a mászás/önálló járás kialakulásáig. A fejlesztés a szülő jelenlétében és közremüködésével zajlik, és részét képezi az otthon is alkalmazható testhelyzeteknek, eszközök alkalmazási lehetőségeinek, illetve tornagyakorlatoknak a betanítása.

- Csoportos aktív gyógytorna: 1,5-2 éves kortól, a mászás elsajátítását követően javasoljuk, a szülő aktív részvételével, amennyiben a gyermek már képes a csoportnormák elfogadására. A csoportba sorolás kritériumai: életkor, diagnózis, mozgásfejlettség aktuális szintje, társuló fogyatékosságok.

- Dévény-féle speciális manuális technika (DSGM): központi idegrendszer vagy perifériás idegek bármely eredetű sérülése miatt kialakuló állapot, ortopédiai deformitások esetén javasolt. Célja, hogy a mozgásrendszerben rejlő zsugorodások (izom, ín) elhárításával megteremtse a mozgás anatómiai feltételeit, valamint az idegrendszer ingerlésével felgyorsítsa a meglassult mozgásfejlődést. A szakember az izom-, ín- és kötőszövetrendszert speciális manuális technikával (kézzel) kezeli. A folyamatos ellátás biztosítása érdekében Központunkban hetente egy alkalommal és maximum két tanéven keresztül tudunk DSGM terápiát biztosítani.

- Bobath Koncepció - A módszer két alap pillére: gátlás és kiépítés. A kóros reflextevékenység gátlása és az izomtónus normalizálása, reflexgátló alaphelyzetek és fogások alkalmazásával. Ezek segítségével kiküszöböli a felesleges (kóros) mozgáselemeket, és a testhelyzetek fenntartásához szükséges pluszenergiákat csökkenti. Normál tartási- és mozgásformák kialakítása: követi a normál mozgásfejlődés menetét, segítő, ún. facilitáló fogásokat alkalmaz. A facilitáló fogások olyan terápiás fogások, amelyek alkalmazásával egy testhelyzet vagy mozgás könnyebben kivitelezhető. Indikációk: központi idegrendszeri sérülés (laesio) következtében kialakuló tónus, mozgás és funkcióbeli eltérés.

- Tervezett Szenzomotoros Tréning (TSMT): Mozgásos feladatokra épülő terápia, mely előre tervezett ingerekkel indít el spontán fejlődést a gyermekeknél. Elsősorban az egyensúlyérzéket és a mozgások összerendezését segíti, de változásokat eredményez a viselkedésben, a magatartásban és a figyelemben is. A találkozások gyakorisága a terápiát nyújtó szakemberrel történő egyéni megállapodás alapján történik, a terápia otthon, megadott rendszeresen végzendő feladatsort ad a család kezébe. Indikációk lehetnek a mozgáskoordinációs, mozgástervezési problémák, megkésett pszichomotoros fejlődés, egyensúlyzavar, szenzoros integrációs zavar, éretlenség, megkésett beszédfejlődés, hiperaktivitás, figyelemzavar, rizikós koraszülöttség, adaptációs-szabályozási nehézségek, viselkedésszervezési problémák, autizmus spektrum zavar.

- DSZIT terápia a szenzoros integrációs terápia azon hazai változata, amelynek a dinamikus szenzoros integrációs terápia nevet kapta. A dinamikus szó sokféle jelentéstartományából mindenekelőtt azt emelnénk ki, hogy pszichoterápiás szemlélettel dolgozik, amelyben az érzékszervi-mozgásos-kognitív történések mellett kiemelt figyelmet szentel a lelki történések kapcsolati dinamikájának. Dinamikusan igyekszi a világot, a gyermekek világát látni, változásában, fejlődésében, mozgásában (DSZITT $\left.{ }^{\circledR}, 2015\right)$.

- $B M C^{\circledR}$ Szomatikus Mozgásnevelés $A B^{\circledR} C^{\circledR}$ a mozgásfejlődési minták és a viselkedési minták közötti összefüggéseket tanulmányozza, és abból indul ki, hogy a tanulási folyamatok alapja és első formája: a mozgás és az érintés. $B M C^{\circledR}$ terápiás óra során az érintés, a mozgás és hangi kifejezés eszközeit 
használjuk. Az aktív mozgások késztetése mellett nagy hangsúlyt kapnak a tónusváltozást, az önészlelést és az izgalmi szint szabályzását szolgáló gyakorlatok, helyzetek. Például a különböző ringatások, az érintésekkel kísért, vagy támogatott mozgások. A terápia indikációja pl. izomtónusbeli eltérés, általános fejlődésbeli megkésettség vagy megakadás, szenzoros integrációs zavar lehet.

- Zeneterápia, melynek során a zenét, mint eszközt használjuk személyiségfejlesztés, korrekció, gyógyítás, és rehabilitáció érdekében. Céljai a gyermek sérülésének és a család igényeinek megfelelően a magatartászavarok enyhítése, mozgás-, figyelem- és kommunikációfejlesztés, a szorongások oldása, a bölcsődére és az óvodára való előkészítés, az anya-gyermek kapcsolatban az elfogadás segítése lehetnek. A zeneterápiás foglalkozás egyéni vagy kiscsoportos formában valósul meg (a gyermek kezdeti állapota határozza meg, hogy melyik a megfelelő). A zeneterapeuta a gyógypedagógia keretében a sérült funkciók korrekciójában, valamint a kompenzatorikus átszerveződés folyamatában zeneterápiás és zenei pszichoterápiás eljárásokat alkalmaz. A szorongó, gátlásokkal küzdő gyermekek feloldódnak az éneklés, a közös játék és a zenére történő improvizatív mozgás hatására. A zene fejleszti a gyermek mozgáskoncentrációját, növeli mozgásigényét. $A z$ ismétlődő játékmozdulatok összerendezett mozgásra késztetnek. Az 1-2 éves gyermekek erőteljesen igénylik a dalok mozgással történő kíséretét. Emellett az édesanya jelenlétében még hatékonyabban fogadják be a gyermekek a zenei élményeket, az együtt megélt történések, a jó hangulat terápiás hatással bír mindkettejükre. Az oldott vidám légkör, gyermekük öröme, bátor próbálkozásai oldják az édesanyák szorongásait. $A$ zene együttes élménye valódi közösséggé kovácsolja a csoportokat, amely a foglalkozásokon kívül is érezteti hatását.

- Pszichológiai ellátás: indokolt lehet minden olyan esetben, amikor a pszichológia eszközeivel megközelíthető probléma áll fenn, akár a gyermek pszichés és/vagy testi müködésében, akár a környezetével való kapcsolatában. Formája a család igényeinek megfelelően többféle lehet:

- a pszichológus csak az anyával/szülőkkel konzultál, egy vagy több alkalommal a felmerülő nevelési, gondozási, érzelmi, viselkedési problémákról

- a pszichológus a gyermeket és az anyát/szülőket együtt fogadja, megfigyelve, megismerve kapcsolatukat, a helyszínen történtekről is konzultál, illetve a gyerekkel a szülők jelenlétében foglalkozik, együtt értelmezik viselkedését stb.

- a pszichológus, miután beszélt az anyával/szülőkkel, a gyermeket egyedül fogadja, részesíti pszichoterápiában, ennek kiegészítéseként időnként az anyával/szülőkkel konzultál

- a gyerek fejlesztését végző gyógypedagógus olyan nehézséget észlel, amihez pszichológus kolléga közremüködését kéri. A két szakember közös megbeszélésen megállapodik a gyerek érdekében történő együttműködés formájában

- az ellátott gyermek testvére szorul pszichológiai ellátásra, pszichoterápiára. Ezt is kérheti a szülő, vagy az ő elmondása alapján ajánlhatja neki a gyógypedagógus vagy a pszichológus (BKFK, 2014).

Intézményünk szakemberei évről-évre új fajta, az érintett gyermekek és családjaik igényeit figyelembevevő összetett, komplex terápiás formákat dolgoznak ki, majd alkalmaznak. E kereteken belül több gyógypedagógus és/vagy terapeuta együttes munkáján alapulva, kiscsoportokban zajlik a fejlesztés. Pl. gyógypedagógia és mozgásterápia együttese, gyógypedagógia és zeneterápia ötvözése, vagy a Bölcsődal, amely során a zeneterápia és a szenzoros tréning együttese képezi a fejlesztést (Fisher és Wittman, 2012; Szücs, 2012). 
Czeizel Barbara - Kemény Gabriella:

\section{Prevenciós Program a koraszülöttek ellátására a Budapesti Korai Fejlesztő Központban}

Magyarországon majdnem minden 10. gyermek idő előtt, tehát a terhesség 37 . hete előtt jön a világra. A fejlődő orvostudománynak köszönhetően egyre gyakrabban maradnak életben az extrém korán, a terhesség 25-26 hetében világra jött, 1000 gr születési súlyt el nem elérő gyermekek is. Mára az élve szülés határát a 24. fogamzási hétre teszik, a súlyhatáréket pedig 550 grammban állapítják meg. A magzati agyfejlődés számára az anyai környezet idő előtti elhagyása fokozott kockázatot jelent, még akkor is, ha őket jól felszerelt kórházi osztályon nagy tapasztalatú szakemberek fogadják A koraszülött újszülötteknél a fiziológiás méhen belüli fejlődés drasztikusan megszakad, az egyes szervrendszerek idő elött, éretlen, sérülékeny állapotban kényszerülnek alkalmazkodni a külvilági ingerfeltételekhez. Az éretlen keringési, légző- és idegrendszerre nézve egyaránt fokozott megterhelést jelent az életfunkciók biztosítása. A figyelem az utóbbi időben a kis súlyú, éretlen koraszülöttek felé fordult, de a kevésbé rizikós koraszülöttek és családjaik sem maradhatnak szakszerű nyomonkövetés nélkül a hypoxia, az agyvérzés és a fertőzés által az agyi károsodás veszélye miatt. A törékeny, sérülékeny idő előtt világra jött kisbaba léte a család számára is fokozott emocionális terhet jelent. Az idő előtt (1500 gr. születési súly alatt) született kisbabák kb. 10\%-ánál az idegrendszer valamilyen fokú károsodásával számolnunk kell. A kezdeti időszakot zökkenőmentesen átvészelő gyermekeknél is találhatunk a későbbiekben enyhébb zavarokat a tanulás, a figyelem, a viselkedésszabályozás terén. Legkönynyebb egy spektrum mentén elhelyezni ezeket a csecsemőket és kisgyermekeket: a spektrum egyik végpontját a fejlődésmenetükben jelentősen akadályozott, súlyosanhalmozottan sérült volt koraszülött gyermekek állnak, a középső zónát a megkésett pszichomotoros fejlődésű gyermekek alkotják, és a spektrum legjobb életkilátásokkal rendelkező gyermekcsoportjába az ép értelmi képességekkel rendelkező, de a részképesség zavarok szempontjából veszélyeztetett koraszülött gyermekek tartoznak.

A koraszülött gyermekek fejlődési esélyeinek optimalizálása érdekében különös jelentősége van a kora gyermekkori intervenciónak. A fenti spektrum mentén gondolkodva mindhárom (1. fejlödésmenetükben jelentösen akadályozott, 2. megkésett pszichomotoros fejlettségü, 3. ép értelmü, veszélyeztetett gyermek) gyermekcsoportnál, más-más hangsúllyal és módszertannal, indokolt a korai intervenciós programok indítása. Mivel a klinikai jelek néhány hetes korban nem mindig feltűnőek, és a kórfolyamat alig észlelhető enyhe tüneteket okoz, a gyermek rendszeres szakorvosi ellenőrző vizsgálatai és a szülők, családtagok, védőnők értékes megfigyelései együttesen teszik lehetővé a fejlődési elmaradás legkisebb jelének azonnali felfedezését. A tünetek minél korábbi kiszürése azért is fontos, mert bizonyos esetekben a megfelelő aktív korai terápia megkezdése reorganizálja a kóros agyi folyamatokat, megszünteti a kórfolyamat által létrehozott funkciózavarokat, kieséseket, ill. más esetekben a korán megkezdett intervenció segítségével, a folyamatos nyomon követés során a csecsemök és családjaik bekerülnek egy olyan ellátó rendszerbe, melyben gyógypedagógusok, mozgásfejlesztő szakemberek és szakorvosok együtt vesznek részt az eltérően fejlödő csecsemők fejlesztése érdekében. Vannak olyan kórképek, amikor már a méhen belüli diagnosztika során vagy a megszületés pillanatában nyilvánvalóvá válik, hogy az újszülött fejlődésmenetében akadályozottá fog válni, például egyes szindrómák, fejlődési rendellenességek, súlyos idegrendszeri károsodás eseteiben. Ilyenkor nem az a kérdés, hogy a gyermek és családja részesévé váljon-e a rehabilitáció folyamatának, sokkal inkább az, hogy a rehabilitáció különböző területein (orvosi, pedagógiai, 
A korai fejlesztéstől a családközpontú kora gyermekkori intervencióig. A törvényi szabályozástól...

szociális) dolgozó szakemberek mennyire tudnak összehangoltan működni, tudnak-e komplex ellátást nyújtani, ezt az életkor előrehaladásával és a gyermek állapotváltozásainak figyelembevételével képesek-e megfelelően módosítani, valamint ezzel egy időben a folyamatosságot biztosítani.

\section{A Prevenciós Program elemei}

A program célja, hogy a sérült, veszélyeztetett kisbabák a Neonatális Intenzív Centrumokból vagy Perinatális Intenzív Centrumokból kikerülve rendszeres neurológiai utógondozásba kerüljenek, és ezzel párhuzamosan, ha szükséges, a lehető legrövidebb idő múlva találkozzanak a gyermek fejlődését nyomon követő gyógypedagógus, pszichológus illetve gyógytornász szakemberrel, és elkezdődhessen a tanácsadás. A modern kora gyermekkori intervenció - mint ahogy ezt korábban is hangsúlyoztuk - családközpontú, nem kizárólag a koraszülött gyermekre koncentrál, hanem a gyermeket körülvevő környezetet, a család mentálhigiénés állapotát is javítani igyekszik annak érdekében, hogy a szülő gyermekét a lehetőségekhez képest maximálisan értő gondozóvá válhasson.

A Prevenciós Program területén is detektálható Központunk fontos alapelve, hogy a szülőknek pontos tájékoztatást adjunk gyermekük állapotáról, a diagnosztikus és terápiás lehetőségekről. A tanácsok, kezelések csak akkor érik el céljukat, ha ők pontosan értik, hogy mi miért történik.

A koraszülötteket ellátó programunk szolgáltatásai:

- A gyermekneurológus általi fejlődésneurológiai nyomonkövetés, melynek célja, hogy a gyermek fejlődésének irányát és ütemét figyelje. A neurológus ismeri az éretlenség jeleit, figyelembe veszi a várható spontán érés folyamatát és az egyéni különbségeket, hiszen a gyermek genetikailag meghatározott habitusa és a születés körüli események együttesen jelentősen befolyásolják a fejlődést. A neurológiai vizsgálat során fény derül arra, hogy van-e olyan organikus neurológiai eltérés, amely a fejlődést akadályozza és hogyan lehet ezen orvosi beavatkozásokkal, gyógyszerekkel segíteni. (Például: újszülöttkori görcs-állapotok, agynyomás-fokozódás, anyagcsere-betegségek stb.) Ellenőrizni kell az érzékszervek állapotát és spontán érésük figyelembevételével dönteni a megfelelő szakemberek bevonásával arról, hogy kell-e és ha igen, akkor milyen korrekció szükséges. (Például hallókészülék átmeneti használata.) Az ún. elemi mozgásminták és az izomtónus gondos és többszöri vizsgálata alapján egyénileg kell dönteni a mozgásterápia beállításáról, úgy, hogy a szakmai szempontok érvényesítése mellett, a család számára térben és időben, valamint anyagilag is elérhető legyen a szolgáltatás.

- Az intervenciós programcsomag gerincét a korai komplex gyógypedagógiai kísérés, fejlesztés és tanácsadás adja. A család "gyógypedagógusa” egyben a gyermek körül felálló interdiszciplináris team koordinátora is. A koraszülött gyermek fejlesztése az egyéni problémák tükrében alakul. A gyógypedagógus a gyermek állapotának és a család igényeinek megfelelően foglalkozhat evési, alvási nehézségekkel, ill. az ingerfeldolgozás nehezítettsége révén előálló neuroszenzoros problémákkal. Például akadályozott lehet a taktilis/haptikus / kinesztetikus ingerek feldolgozása, ill. nehézségek lehetnek a vizuális, vagy akusztikus csatornán keresztül érkező ingerek feldolgozásában. Ezekkel a problémákkal a gyógypedagógus a fokozatosság és a normalizáció elveit szem előtt tartva a szülő bevonásával (sőt közvetítésével) dolgozik. Kezdetben a szakember kéthetente találkozik a családdal, hogy megfigyelje, hogyan változik a gyermek mozgása, figyelme, hogyan alakulnak csecsemőkori kommunikációs és szociális készségei. Az első hat-nyolc találkozást követően javaslatot tesz 
a találkozások gyakoriságára, aszerint, hogy a kisgyermek fejlődése kevesebb vagy éppen több segítséget igényel.

- Mozgásterápiák - A koraszülött gyermekek nagy részénél akadályozott lehet a mozgásfejlődés, késnek a mozgásos fejlődési mérföldkövek. Ilyenkor a gyermek körül felálló intervenciós team munkájába a korai mozgásfejlődésre specializálódott gyógytornász is bekapcsolódik. Akár az izmok speciális manuális technikával (DSGM) történő stimulálása, akár a gyermek aktív mozgásának elősegítése folyik a mozgásterápia során, a cél minden esetben az, hogy az izmok tónusa normalizálódjon, és a gyermek a normál mozgásfejlődés lépcsőin keresztül menve önálló helyváltoztatásra képes gyermekké váljon. Az éretlen idegrendszer fejlődésnek elősegítése történhet Tervezett Szenzomotoros Tréning alkalmazásával is.

- Bölcsődal vagy Hangolódó- csoportos foglalkozás, melynek keretében munkatársaink a Zeneterápia és a Tervezett Szenzomotoros Trénig ill. a BMC® Szomatikus Mozgásnevelés elemeit ötvözik. A zene alapvető tényező a kisgyermekek fejlődésében; az édesanya hangja a legcsodálatosabb zene számukra. A korai anya-gyermek párbeszéd, zenei kommunikáció segíti a szocializációt, befolyásolja a felnőttkori kommunikációs rendszert. A minőségi anya-gyermek kapcsolat pedig a személyiség fejlődésének elsődleges meghatározója. A korai mozgásos élmények már kiscsecsemő korban segítik az idegrendszeri működés érését, összerendezését, a külvilághoz való alkalmazkodást, a megfelelő válaszreakciók kialakulását. Koraszülöttség esetén különösen fontos, hogy a csecsemőt megfelelő zenei és szenzoros ingeregyüttesekhez juttassuk, hiszen az idegrendszer és az érzékszervek stimulálásával segítünk korrigálni a születés utáni időszak mozgásos, kommunikációs és szociális élményeinek eltérő alakulását. Azáltal, hogy a gyermekek aktuális igényeinek megfelelően tesszük ingergazdaggá környezetüket a zene- és mozgásterápiák ötvözésével, egyúttal elejét vehetjük az esetleges későbbi problémáknak a tanulás, vagy a viselkedés terén. A Hangolódó csoport programja is a mozgásos, a zenei és a szociális élmények együttes fejlesztő hatása köré épül. A foglalkozások egyszerre hasznosak a részvevő gyereknek - akár a 2 hónapos kortól az 1 éves kornak megfelelő mozgásfejlődési szintig - valamint a szülőnek, aki egyfelől olyan oldott együttlétben lehet a gyermekével, mely mélyíti kapcsolatukat, és segít a szülői érzések kiteljesedésben, másfelől olyan információkat szerez, melyek révén az otthoni gondozási helyzetekben is érvényesíthet bizonyos fejlesztési szempontokat. A gyakorlatokat mindig a gyermekek aktuális fizikai és figyelmi állapotához igazítjuk, hogy az ingerek és azok feldolgozása egyensúlyban legyen. A mozgásos fejlesztéssel azonos értékủnek tartjuk a zene, az ének valamint az intim együttlét során megnyíló figyelem erejét. Ezeket a kitáguló pillanatokat próbáljuk megragadni, a szülő számára is láthatóvá tenni, és fenntartani mind a passzív, mind az aktív mozgásos helyzetekben. Általában arra törekszünk, hogy az aktiváció olyan szintjén dolgozzunk, ahol a gyermek kreatív jelenléttel tud a feladathoz, a helyzethez és a partnerhez viszonyulni. Így ez a játékos, örömteli együttlét egyúttal az izgalmi szint szabályzásának tanulása is, úgy a baba, mint a szülő számára. A foglalkozásokon természetszerüen, a csoport tagjai egyéni figyelmet is kapnak: a szülővel együtt figyeljük, értelmezzük a gyermekek viselkedését, reakcióik természetét, egyéni megnyilvánulásait, majd együtt keresünk újabb támogató helyzeteket, játékokat, és hozzá éneket, mondókát.

- Pszichológiai megsegítés - Súlyosabb emocionális problémák, ill. kötődési nehézségek esetén a teambe pszichológus munkatárs is bekapcsolódik. Az anya-gyermek kapcsolat erősítése zeneterápia segítségével is folyhat. A zeneterápia jótékony hatását kommunikációs és szociális kapcsolatépítési nehézségekkel élö kisgyermekek esetében is tapasztaljuk.

- A gyermekneurológiai konzultáció a programban résztvevő szülőknek és szakembereknek -igény szerint, előzetes bejelentkezés után vehető igénybe. Ezeken 
A korai fejlesztéstől a családközpontú kora gyermekkori intervencióig. A törvényi szabályozástól...

az alkalmakon a kisgyermek fejlődésére vonatkozó orvosi, neurológiai kérdésekre kaphatnak választ gyermekneurológus munkatársunktól.

- A Komplex vizsgálat, melynek során ebben a programban is több szakember (gyermekneurológus, gyógypedagógus, gyógytornász, pszichológus) vizsgálja a gyermeket. Összehangolt módszereikkel a gyermek problémájának, fejlettségének komplex vizsgálatát végzik el. A vizsgálat lezárásaként a szülőkkel átbeszélik az eredményeket és a fejlődés előmozdítása érdekében fejlesztési és terápiás javaslatot tesznek, vagy megmaradhat a nyomonkövetés a gyermek szükségleteihez igazodó gyakorisággal.. A javaslat természetesen intézményünk alapelve szerint nemcsak a gyermek szükségleteit, hanem a család igényeit, lehetőségeit is messzemenően figyelembe veszi.

- Utánkövetö komplex kontrollvizsgálat a gyermek kétéves kora körül. Azon gyermekek számára, akiknek fejlődése megnyugtatóan alakul, a program utolsó állomása a gyermek kétéves kora körül egy újabb, komplex vizsgálat, amelyet attól függetlenül felajánlunk a programban résztvevő családoknak, hogy igénybe vették-e a Korai Fejlesztő Központ szolgáltatásait. A fejlesztésekre és terápiákra továbbra is intézményünkbe járó gyermekeknek körülbelül évente biztosítunk kontroll vizsgálati lehetőséget (Bod és Hajtó, 2012).

Az elmúlt több mint két évtized meghatározó volt a hazai családközpontú kora gyermekkori intervenció szemléletének alakulásában csakúgy, mint a Budapesti Korai Fejlesztő Központ interdiszciplináris protokolljának fejlődésében. E két folyamat - talán szerénytelenség nélkül állíthatjuk - kölcsönös hatással volt egymásra. Ez a kölcsönösség - melyet alapjaiban befolyásol az eltérő fejlődésű kisgyermekek és családjaik részéről felmerülő partneri szemléletet elváró igény - határozza meg egyértelműen a mai napig mind a gyakorlat, mind a holisztikus szempontú elmélet formálódását hazánkban.

\section{Irodalom}

Bod Mária és Hajtó Krisztina (2012): Koraszülött Prevenciós Program - új ellátási forma a Korai Fejlesztő Központban. Fejlesztő pedagógia: pedagógiai szakfolyóirat 23. (4-5), 103-110.

Borbély Sjoukje és Kovács Andrea (2012): Partnerek lehetünk-e a szülö és szakember közötti kapcsolatban? Fejlesztő pedagógia: pedagógiai szakfolyóirat 23. (4-5), 12-21.

Budapesti Korai Fejlesztő Központ Pedagógiai Programja (BKFK) (2014): BKFK, Budapest.

Czeizel Barbara (2009a): A kora gyermekkori intervenció múltja, jelene és remélt jövője: Gyógypedagógiai Szemle 37. (2-3.), 153-160.

Czeizel Barbara (2009b): A kora gyermekkori intervenció magyarországi hálózatának kiépítése - szakmai, stratégiai javaslatok. In: Kőpatakiné Mészáros Mária (szerk.) Együttnevelés - Határon innen és túl. Oktatáskutató és Fejlesztő Intézet, Budapest, 98-118.

Czeizel Barbara (2010): Családközpontú kora gyermekkori intervenció és fejlesztés. In: Radványi Katalin (szerk.) MÁSKÉ(P)P? - Intellektuális fogyatékossággal élő emberek gyógypedagógusainak tankönyve. ELTE BGGYFK, Budapest, 49-55.

Czeizel Barbara (2012): 20 éve a kora gyermekkori intervencióban. Fejlesztő pedagógia: pedagógiai szakfolyóirat 23. (4-5), 4-6.

Czeizel Barbara, Tóth Anikó és Kemény Gabriella (2011): Pilotprogram kifejlesztése és lebonyolítása három célrégióban a kora gyermekkori intervenció rendszerszerü müködésének megalapozásához. Educatio Kft., Budapest.

DSZIT ${ }^{\circledR}$ Mühely www.dszit.hu

ECIPU (2005): Korai fejlesztés. Az európai helyzet elemzése. Kulcstényezők és ajánlások. Európai Ügynökség a Sajátos Nevelési Igényü Tanulók Oktatásának Fejlesztéséért.

ECIPU (2010): Early Childhood Intervention Project Update. European Agency for Development in Special Needs Education. 2010. munkaanyag 
Czeizel Barbara - Kemény Gabriella:

Fischer Gabriella és Wittman Zsuzsanna (2012): Rajmund - Zeneterapeuta és gyógypedagógus együttműködése egy autizmussal élő kisgyermek ellátásában. Fejlesztő pedagógia: pedagógiai szakfolyóirat 23. (4-5), 84-87.

Szűcs Sándor (2012): A gyógytornász szemléletének formálódása a korai fejlesztő teamben végzett vizsgálatok során. Fejlesztő pedagógia: pedagógiai szakfolyóirat 23. (4-5), 26-31.

Tóth Anikó (2000): Komplexitás a korai fejlesztésben. Esetismertetés. Fejlesztő pedagógia: pedagógiai szakfolyóirat 11. (4-5), 17-19. 